МОСИН Василий Иванович - кандидат философских наук, доцент; генеральный директор Тульского социологического иентра (300001, Россия, г. Тула, ул. Гармонная, 28, оф. 39); старший научный сотрудник Центра региональных исторических исследований Тульского государственного педагогического университета им. Л.Н. Толстого (300026, Россия, г. Тула, пр-кт Ленина, 125, кopn.4; mosin55@bk.ru)

\title{
ПРЕМИЯ «ТУЛЬСКИЙ БИЗНЕС» В УСЛОВИЯХ ПАНДЕМИИ
}

Аннотация. В статье автор рассказывает о вручении премии «Тульский бизнес» по итогам 2020 г. Премия «Тульский бизнес» за 10 лет своего существования превратилась в самую авторитетную экономическую награду в Тульской области. Цель премии - выявление лучших на тульском рынке и повышение имиджа компаний-участников. За годы своего существования премия «Тульский бизнес» помогла привлечь в экономику области значительные средства и наладить взаимовыгодное сотрудничество как внутри региона, так и за его пределами.

Пандемия 2020 г. внесла свои коррективы в подведение итогов. Организаторы премии смогли выйти из непростой ситуации в условиях карантина, все элементы торжественности были соблюдены, и вручение премии «Тульский бизнес-2020» стало заметным событием в Тульском регионе.

Ключевые слова: бизнес, премия, пандемия, карантин, экономика

$\mathrm{B}$ от уже 10 лет существует региональная премия «Тульский бизнес». За это время авторитет ее среди предпринимателей, бизнесменов, руководителей предприятий, политиков, работников административных органов, социологов, научных работников настолько возрос, что она стала главной экономической премией в регионе. Среди ее экспертов есть руководители предприятий и общественных организаций, политики, бизнесмены, журналисты и другие авторитетные специалисты в экономической сфере, с чьим мнением считаются и к которым прислушиваются.

При вручении десятой по счету премии «Тульский бизнес» организаторам пришлось изменить формат ее проведения в связи с пандемией в регионе и стране. В условиях пандемии нельзя было проводить мероприятия с привлечением большого числа участников, и церемония награждения лауреатов премии «Тульский бизнес» прошла в формате мини-вручений. Всего было 23 победителя в различных номинациях. Их разделили на несколько групп, и приглашенные VIP-гости (члены экспертного совета премии) вручали награды лично. Торжественные церемонии вручения премии прошли в знаковых местах Тулы и области - Музее оружия, атриуме Тульского кремля, в ТРЦ «Гостиный двор», фотостудии Grange и др.

Также с 21 по 25 декабря прошла неделя премии в СМИ: ежедневно на сайтах партнеров премии публиковались новости, фоторепортажи и видеосюжеты с церемоний вручения.

Победителями премии «Тульский бизнес - 2020» в номинации «Инвестор года» стал тепличный комплекс «Тульский» агропромышленного холдинга «ЭКО-культура»; в номинации «Промышленная компания года» - компания «Щекиноазот»; в номинации «Строительная компания года» - АО Специализированный застройщик «ВНЕШСТРОЙ»; в номинации «Машиностроение» - АО «АК «Туламашзавод»; в номинации «Страховая компания года» - ООО «Страховая Компания «Согласие»; в номинации «Банк года. Лидер отрасли» - Тульское отделение ПАО «Сбербанк»; в номинации «Банк года. Высокие темпы роста и развития сети» - банк ВТБ (ПАО), в номина- 
ции «Транспортная компания года» - МКП «Тулгорэлектротранс»; в номинации «Лучший провайдер цифровых услуг» - ПАО «Ростелеком» в Тульской и Рязанской областях; в номинации «Медицинские услуги» - Центр стоматологии инновационных технологий им. И.Е. Тихонова; в номинации «Управляющая компания года» - ООО «Фаворит»; в номинации «Индустрия развлечений» - ГУ ТО «Тульские парки»; в номинации «Потенциал и перспектива» - завод «Техприбор» (ООО «Дезинтегратор»); в номинации «За высокое качество и сервис» - ООО «Кирпичный завод БРАЕР»; в номинации «За социальную ответственность бизнеса» - региональный оператор ООО «Хартия»; в номинации «Работодатель года» - «Ростелеком Контакт-центр» (АО «МЦ НТТ»); в номинации «За вклад в обеспечение здоровья» - Частное учреждение здравоохранения «Клиническая больница «РЖД-Медицина» города Тула»; в номинации «За реализацию инновационных проектов» - МЦ «Консультант»; в номинации «Репутация и доверие» - филиал АКБ «ФОРА-БАНК» (АО) в г. Калуге; в номинации «Клиентоориентированная компания» - ООО «Клиника Эксперт Тула»; в номинации «Тульский бренд» - «Триумфальная арка»; в номинации «Открытие года» - ООО Специализированный застройщик «Группа компаний «ОСТ».

Победителем народного голосования, которое было открыто в номинации «Лучший виртуальный проект, раскрывающий творческий потенциал нашего региона», стал цикл видеосюжетов Государственного архива Тульской области. Он был снят в честь празднования 500-летия Тульского кремля и посвящен истории городов Большой засечной черты. Проект стартовал в начале июня 2020 г. и завершился в последние дни августа.

Из списка видно, что победители в номинациях представляют практически все основные отрасли жизнедеятельности Тульской области.

MOSIN Vasiliy Ivanovich, Cand.Sci. (Philos.), Associate Professor; General Director of the Tula Sociological Center (of. 39, 28 Garmonnaya St, Tula, Russia, 300001); Senior Researcher at the Center for Regional Historical Research, Tula State Lev Tolstoy Pedagogical University (bld. 4, 125 Lenina Ave, Tula, Russia, 300026; mosin55@bk.ru)

\section{THE AWARD «TULA BUSINESS-2020» IN THE PANDEMIC REALITY}

\footnotetext{
Abstract. In the article, the author considers the award "Tula Business- 2020». For 10 years, "Tula Business" has become the most valuable economic award in the region. Its purpose is to identify the best company in Tula and improve the comprehension of the participants. Over the years, the "Tula Business» award attracts funds to the regional economy and establishes beneficial cooperation for companies both within the region and abroad. The 2020 pandemic makes a difficult situation for the organizers but all the elements of solemnity were observed, and the presentation of the award «Tula Business-2020» becomes a notable event in the region.

Keywords: business, premium, pandemic, quarantine, economy
} 